\title{
Eskişehir'de Bulunan Şadi Çalık Heykelleri Üzerine Bir Değerlendirme
}

\author{
An Evaluation of Şadi Çalik Statues in Eskişehir
}

\section{Selda Alp* ${ }^{\mathbb{C}}$}

\section{Öz}

Cumhuriyetin ilanın ardından yapılmaya başlanan Atatürk heykelleri, Türkiye'nin modern yüzünü ve liderine duyduğu minnettarlığı gösteren önemli sembolik anıtlardır. Bu dönemin önemli sanatçısı Şadi Çalık da hem eğitimci hem de heykeltıraş olarak üzerine düşen görevi üstlenmiştir. 1960 yılından itibaren yaptığı Akhisar, Ayvalık, Bandırma, Batman, Bitlis, Burdur, Edremit, Erzincan, Eskişehir kentleri, Diyarbakır 3. Hava Kuvvetleri Üssü, Ortadoğu Teknik Üniversitesi ve Anadolu Üniversitesi Atatürk anıtlarının birbirinden farklı özellikleri sanatçının bireysel ve özgün olma çabasına girdiğini göstermektedir. Bu makalede sanatçının Eskişehir Valiliği önündeki “Atatürk ve Gençlik Anıtı” ve Anadolu Üniversitesi Yunus Emre Kampüsü’ndeki “Atatürk Heykeli” üzerine bilgiler verilmiştir. Anıtlarda malzeme seçimi ve uyumu, teknik özellikleri, Atatürk'ün parmaklarının kemikli ve narin bir biçimde ele alınışı benzerdir. Rudolf Edwin Belling'in öğrencisi olarak sanat hayatına başlayan Şadi Çalık'ın Eskişehir'deki anıt heykelleri ile ilgili yayınlanan Sakarya gazetesindeki haberleri, Büyükşehir Belediye Başkanı Prof. Dr. Yılmaz Büyükerşen’in anıları ve Çağdaş Sanatlar Müzesi koleksiyonundaki maketleri üzerine değerlendirmeler yapılmıştır.

\section{Anahtar Kelimeler}

Eskişehir, Atatürk heykelleri, Şadi Çalık, heykel, Anadolu Üniversitesi

\begin{abstract}
Atatürk sculptures have been installed since the proclamation of the republic. They are important symbolic monuments that represent the modern side of Turkey and its people's gratitude to their leader. Şadi Çalık, an important artist of 1960's and 1970's, worked as an educator and sculptor. He attempted to make individualist and original Atatürk monuments, as seen in his sculptures in different city squares. His originality and individualism can also be seen in the different characteristics of the Atatürk sculptures in Akhisar, Ayvalık, Bandırma, Batman, Bitlis, Burdur, Edremit, Erzincan, Eskişehir, Diyarbakır $3^{\text {rd }}$ Air Force Base, Middle East Technical University, and Anadolu University. This study provides information on his unpublicized works, Monument of Atatürk and Youth in front of the Eskişehir Governorship and Atatürk Sculpture on the Yunus Emre Campus of Anadolu University. These monuments are similar in terms of the selection and harmony of materials and their technical features. This study also incorporates news about the monuments from the newspaper Sakarya, memoirs of Prof. Dr. Yılmaz Büyükerşen, and some models in the collection of the Museum of Contemporary Arts in Anadolu University.
\end{abstract}

Keywords

Eskişehir, Atatürk statues, Şadi Çalık, statue, Anadolu University

* Sorumlu Yazar: Selda Alp (Dr. Öğr. Üyesi), Anadolu Üniversitesi, Edebiyat Fakültesi, Sanat Tarihi Bölümü, Eskişehir, Türkiye, E-posta: salp@anadolu.edu.tr, ORCID: 0000-0001-6959-145X

Atıf: Alp, Selda. “Eskişehir'de Bulunan Şadi Çalık Heykelleri Üzerine Bir Değerlendirme." Art-Sanat, 16(2021): 31-54 https://doi.org/10.26650/artsanat.2021.16.0002 


\section{Extended Summarv}

Şadi Çalık is one of the artists who come to mind when Turkish sculpture is mentioned; he drew attention with the monuments he made after 1950. As a student of Rudolf Edwin Belling, he continued his art life in the metal workshop of the State Academy of Fine Arts in 1959 and became popular, receiving increasing number of orders over time. In those years, he was impressed by the abstract art of Paris.

This study discusses the opening of his unpublicized work Monument of Atatürk and Youth in front of Eskişehir Governorship, financial support of Sakarya and the citizens of Eskişehir, ceremonies, and cost of the monument. Sakarya, one of the local newspapers in Eskişehir, recorded citizens' protests, nongovernmental organizations, and students and the work and activities carried out in line with the request for an Atatürk monument. In his memoirs, Prof. Dr. Yılmaz Büyükerşen, who had been engaged in politics and art since he was a student, said that no Atatürk sculptures were made in the city until 1959.

In the competition held for Monument of Atatürk and Youth in Eskişehir in 1962, a jury consisting of sculptor Ali Hadi Bara, architect Ahsen Yapanar, and Nezih Eldem chose Şadi Çalık as the winner. After he completed the monument in his workshop on Plaj Yolu Street, Istanbul, an opening ceremony was held on September 28, 1962, at 3:00 p.m. with the participation of Cemal Gürsel, Turkey's president at the time.

Although Monument of Atatürk and Youth was not one of the first monuments to be made after the proclamation of the republic, it is a unique example for its dimensions and ramp arrangement. Andesite coating was used for the ramp and pedestal, and marble coating was used for the monument; the Atatürk sculpture was made of bronze, and its square cubic pedestal was made of gray-green marble. Atatürk was located in the middle at the end of the ramp at a height of 188 centimeters, embracing the entire square. The height of the sculpture is 360 centimeters, 4 meters with its pedestal. Atatürk is depicted in civilian clothes and looks majestic in a suit and long coat. The pedestal has the inscription of the artist and the caster on it: SCULPTOR M. ŞADI ÇALIK is written on the right side of the pedestal, and CASTER M. YETKINER NAZILLLI is written on its left side.

Male and female Turkish youth figures are located on the right side of the Atatürk sculpture, and on the left side, there is a block with "Atatürk's Address to the Turkish Youth" written on it. Atatürk points at the youth figures with his right hand. The three young figures in the first line have torches in their hands, and of the figures that raise the lit torches with their right hands, two are men and one is a woman. The male figure on the right side is in civilian clothes; the torch in his right hand represents public resistance; and the book in his left hand represents the rise of the Republic of Turkey with educated youth. 
The third part of the monument displays the "Atatürk's Address to the Turkish Youth" and "The Independence War" reliefs, which depict nine figures: seven soldiers, Atatürk, and an Anatolian woman. From the left, the first two figures are cavalry soldiers attacking the enemy on horseback at full speed; as an indicator of their speed, the stones on the ground are chipped. The third, fourth, and fifth figures, which constitute a triple composition, are dynamic and active, holding their weapons in different ways. Atatürk is standing with his right hand next to a gun carriage and wearing a military cloak, ordering, "Armies, your first goal is the Mediterranean, forward!" He is depicted as a commander who controls every moment of the war, with his binoculars in his hand, gun on his belt, and long boots on his feet.

The second monument Şadi Çalık made in Eskişehir is the Atatürk sculpture in front of the Faculty of Law, Anadolu University, in the area used for ceremonies. It is a bronze sculpture, with a travertine pedestal. The Atatürk figure is about 2 meters tall. It is in the middle of a rectangular pedestal, and Atatürk's figure dons civilian clothes. His arms lean on the pedestal, with his right elbow parallel with his body and the book he holds lateral to his chest. His left arm lies on the pedestal, his hand holding it. The sculpture is seen frontally, depicting Atatürk seated with his legs bent at the knees; his left leg is placed flat on the ground supported by the heel, while his right leg is extended forward with the knee bent.

Today, there are two plaster models of Atatürk of different dimensions in the Anadolu University Museum of Contemporary Arts's collection; one measures $58 \times 52 \times 68$ centimeters, while the other measures $49 \times 9 \times 12$ centimeters. The larger model only depicts the sculpture, whereas the smaller model shows that the inscription will be written on the sides of the pedestal. The smaller model has random letters that do not spell out any meaningful words. According to the model, the artist planned to write a four-line inscription; he showed these models to Prof. Dr. Orhan Oğuz, the president of the academy at the time, and his assistant, Prof. Dr. Y1lmaz Büyükerşen. The monument was completed without the pedestal inscriptions shown in the models.

Monument of Atatürk and Youth and the Atatürk Sculpture are unique monuments that are striking because of the selection and harmony of materials, technical characteristics, and angular forms that have a certain unpretentious plastic characteristic. The Atatürk sculptures made by Şadi Çalık, an artist who tried to be unique, will continue to be symbols of Eskişehir. 


\section{Giriş}

Anadolu'nun aydınlık yüzü olarak bilinen Eskişehir kenti Cumhuriyet'in ilanıyla birlikte başlayan bir değişimle bugünkü görünümüne kavuşmuştur. Kentin merkez noktası olarak tanınan Vilayet Meydanı bu dönemden günümüze ulaşan yönetim merkezidir. Eskişehir Vilayet Meydanı, 1945 yılında Bayındırlık Bakanlığı Şehircilik Fen Heyeti tarafından kentin Hükümet Konağ i ile çevresinin imar planı ve meydan düzenlemesiyle birlikte tasarlanmıştır ${ }^{1}$. Meydanın içinde yer alan Hükümet Konağ Binas 1948 yılında, Merkez Binası 1952 yılında, Eskişehir Adliyesi ise 1949 yılında yaptırılmıştır. Meydanın önemli yapılarından biri olan Hükümet Konağı dönemin mimarlarından Bedri Uçar, Merkez Bankası ise Orhan Bolak tarafından inşa edilmiştir. Her iki mimar da dönemin modern ruhunu yansıtan stilleri ile dikkat çekmektedir. Cumhuriyetin modernleşme ideolojisine uygun olarak oluşturulan vilayet meydanında 1949-1962 yılları arasında eksik olan tek şey anıtsal nitelikli Atatürk heykelidir. Atatürk heykeli de Vilayet Meydanı'na yapılan yukarıda adı geçen yapılarla aynı ruhu yansıtabilecek bir sanatçı olan Şadi Çalık’a yaptırılmıştır.

Çalık, Türk heykeli deyince akla gelen ilk sanatçılardan biri olarak 1950 yılından itibaren yaptığı anıtlarla dikkati çekmiştir. Sanatçının sanat hayatını etkileyen ilk önemli isim Akademi'de eğitim aldığg Rudolf Edwin Belling’tir².

\section{Şadi Çalık ve Rudolf Edwin Belling}

Şadi Çalık, İlhan Koman, Hüseyin Anka Özkan, Hüseyin Gezer, Zerrin Bölükbaş1 ile birlikte Rudolf Edwin Belling'in öğrencisi olmuştur. 1940 yılında Akademide öğrenim gördüğü sırada Heykel Bölümü’nün başında olan Belling'den istenen şey Cumhuriyet ideolojisini duyurmak adına bir araç olarak ele alınan sanatın içinde anıt heykel yapabilecek Türk heykeltıraşları yetiştirmesidir ${ }^{3}$. Belling, Akademide modern sanata dair ve Avrupa'da ortaya çıkan çağdaş akımlara bağlı eğitimden ziyade klasik bir heykel eğitimi vermeyi tercih etmiş̧ir. Kendisi ile bütünleştirdiği soyut sanat gibi uygulamalara yönelimi öğrencilerini etkilemiştir. Sanatçı ilk başta öğrencilerinin Klasik heykeli iyi kavramalarını savunmuş; Belling'in bu tutumu atölyelerin bölünmesi ile sonuçlanmıştır".

1950’lerde Türk heykel sanatında etkisini gösteren soyut sanat biçimi heykeltıraş Şadi Çalık'ın da etkilendiği bir biçim dili olmuştur. Bu yıllarda Çalık yanında Ali Hadi Bara, Zühtü Müridoğlu ve İlhan Koman gibi soyut eserler veren önemli heykeltıraşlar

1 Deniz Özkut, "Eskişehir'de Modern Hafizanın Yerel İzleri”, TÜBA-KED 16 (2017), 40.

2 Belling'in hayatı ve sanatı için bakınız Vildan Çetintaş, "Rudolf Edwin Belling ve Atölyesi” (Doktora tezi, Hacettepe Üniversitesi, 2003).

3 Çetintaş, "Rudolf Edwin Belling ve Atölyesi”, 173.

4 Nurullah Berk ve Hüseyin Gezer, 50. Yılın Türk Resim ve Heykeli (İstanbul: Türkiye İş Bankası Yayınları, 1973), 124. 
dönemin talepleri doğrultusunda yaptıkları anıt heykellerde klasik anlayıştaki uygulamaların dışına çıkmak istemiş ve bunu yaptıkları anıtlarda göstermişlerdir.

Belling atölyesinde akademik kurallara bağlı eğitim alan Çalık'ın figüratif sanattan soyuta uzanan farklı biçimlerde bir üslubu bulunmaktadır. 1940-44 yıllarında İzmir Fuarı Hayvanat Bahçesi için yaptığı Atbaşları (1940), Masadakiler (1944), Kuşlu Kadın Figürü (1941-44), Yatan Kadın (1941-44), Duran Kadın, (1941-44), Asaf Halet Çelebi Büstü (1942) ve Hüseyin Batuhan Büstü (1941) gibi çalışmaları sanatçının Klasik, natüralist ve realist eserlerine örnek verilebilir ${ }^{5}$.

\section{Şadi Çalık'ın Paris Yılları}

1950 yılında Paris'e giden Şadi Çalık, Rue Grand Chaumiere'deki Soyut Sanat Atölyesi'nde ve Güzel Sanatlar Akademisi'nde çalışmalar yapmıştır. ${ }^{6}$ O dönemde Türk sanatçıların özveriyle çalıştığı ve farklı sanat olaylarının yoğun yaşandığı bir sanat merkezi olan Paris'te II. Dünya Savaşı sonrası modern sanatçılar arasında, klasikler, yenilikçiler ve onlardan farklı olarak bulunduğu çağın tanığı olan toplumsal gerçekçiler ile soyut sanatçılar arasında tatlı rekabetler yaşanmaktadır. Genç sanatçılar, plastik sanatlarda yeni ve ödünsüz amaçlarıyla hem kendi yerlerini belirleme hem de savaş sonrası yeniden kuruluş döneminde sanatın da yeniden yapılanması ve insanı ilgilendiren tüm etkinliklerle bütünleşme çabası içine girmişlerdir. Bu dönemi yaşayan sanatçılar için "savaşın yıkıntıları arasında içinde insan ve mekân ilişkisini yeniden tanımlamak ve kurmak" sanatın güncel gerekliliği olmuştur. Kendini soyut sanata adayan André Bloc'un 20. yüzyılın estetik tartışmaları üzerindeki etkisi dönemin sanat ve mimarlık dergileri, 1952 yılında kurduğu "Groupe Espace" içindeki aydın, mimar ve sanatç1larla desteklenmiştir?.

Bloc öncülügünde yapılan sanatsal ve mimarlık faaliyetlerinden etkilenen Türk sanatçılarda çağdaş sanatın başkenti olarak anılan Paris’te ve diğer Avrupa kentlerinde sergiler açarak ortamın bir parçası olmuşlardır. Bu yıllarda Paris’te yaşayan Çalık da sanat dergilerinden, basından ve heykel atölyelerinden güncel sanatı takip etmiş ve kendini bu ortamın parçası olarak görmeye başlamıştır. Belling ve Paris'in şekillendirdiği kübist ve soyut biçim dili bu yıllarda yaratıcılıkla örtüşünce Çalık'ın

5 Siren Çalık, Şadi Çalık (İstanbul: İş Bankası Kültür Yayınları, 2004), 67, 68, 69, 70,71'de eserlerin fotoğrafları verilmiştir.

6 Hüseyin Gezer, Cumhuriyet Dönemi Türk Heykeli (Ankara: Türkiye İş Bankası Yayınları, 1984), 197; Çalık, Şadi Çalık, 23.

7 Le Groupe Espace, "Le Groupe Espace Manifeste”, L'Architecture d'Aujourd'hui (1951), 5.

8 Bugün değeri daha iyi anlaşılan heykeltıraş André Bloc öncülügünde Art d'aujourd'hui (Bugünün Sanatı) (1949-1954), Aujourd'hui:art et architecture (1955-1967) (Bugün Sanat ve Mimarlık) isimli basılan dergilerde sanatçılar zamanın sorunları karşısında sadece eser üretmek değil yazmak zorunda olduklarını, mimarlı̆̆ın ve yeni konseptlerin tanımlanmasında sanatın sentezlenmesini, mekanla kurulan ilişki ile sanat eserlerini tanımlamıștır. http://www.versailles.archi.fr/pdf_actu/programme_andre\%20BLOC\%202015.pdf (Erişim 27 Şubat 2020) 
önemli heykelleri ortaya çıkmıştır. Bu döneminde alçı ve demir malzeme kullanan sanatçı duygularını soyut biçimlerle anlatmayı seçmiştir. Çalık, 1951 yılında Paris'ten Paris Kuşu adlı soyut bir heykelle dönmüş; hemen ardından ise 1952 yılında İlhan Koman ve Zühtü Müridoğlu ile birlikte Anıtkabir kabartmalarını tasarlamıştır. ${ }^{9} \mathrm{Bu}$ yıllar Belling'in akademideki konuşmalarında da heykel ve mimari iş birliğini ele aldığ 1 yıllardır ${ }^{10}$.

Sanatçının Zühtü Müridoğlu, İlhan Koman, Ali Hadi Bara gibi isimlerle kurduğu dostluklar, atölye ilişkileri ve benzer sanat söylemleri yaptığı eserlerde kendini bu yıllarda göstermeye başlamıştır. 1955 yılında yaptığı mimariye bağlı olarak tasarladığg Etibank Rölyefi ile mobilya ve sanatı birleştirdiği Demir İskemle, Koltuk ve Demir Kompozisyonu I. gibi eserlerinde Belling'in etkileri net bir biçimde görülmektedir. Sanat hayatına 1959 yılında Devlet Güzel Sanatlar Akademisi metal atölyesinde devam ederek aldığı siparişlerle popüler bir sanatçı olmuştur. Çalık bu yıllarda Paris'in soyut sanat gündeminden etkilendiğini yaptığı soyut eserler yanında Grup Espas 'ın Türkiye şubesinin kurulmasının içinde yer alması ile de göstermiştir.

\section{Türk Grup Espas ve Çalık}

1953 yılında İlhan Koman, Sadi Öziş, Ali Hadi Bara ve mimar Tarık Carım'ın Grup Espas'ın Türkiye şubesini kurmaları ve plastik sanatlar ile mimari arasında ilişkileri değerlendirmeleri bu dönem sanatçılarının mimarlar ile birlikte çalışmalarını sağlamıştır ${ }^{11}$. Grup içinde yer alan veya yer almayan 1950 'li ve 60'lı y1llarda aktif olarak çalışan Şadi Çalık, Kuzgun Acar, Salih Acar, Ali Hadi Bara, Bedri Rahmi Eyüboğlu, Atilla Galatalı, Neşet Günal, Jale Yılmabaşar, Füreya Koral gibi farklı alanlarda uzmanlaşan ressam, heykeltıraş ve seramik sanatçıları dönemin mimarları ile ortak projelerde çalışmış; bugüne ulaşan önemli sanat eserleri üretmişlerdir. İstanbul Divan Oteli'nin duvarlarında yer alan seramik ve vitray panoları, Vakko Kumaş Fabrikası'nın heykelleri, Şadi Çalık'ın İstanbul Harbiye'de Konak Sineması için yaptığı "milli dans" rölyefleri gibi örnekler bu dönem sanatçı ve mimar iş birliği ile günümüze ulaşan Grup Espas'ın öngörüleriyle tasarlanmış akla ilk gelen uygulamalardır ${ }^{12}$.

1955-1959 yılları arasında İlhan Koman, Şadi Öziş, Mazhar Süleymangil ile ortak açtıkları Şişli'deki Kare Metal atölyesinde de demir boru ve sactan yaptıkları mobil-

9 Çalık, Şadi Çalık, 42.

10 Belling ve Akademideki yılları için bakınız Gezer, Cumhuriyet Dönemi Türk Heykeli, 1984, 325; Zeynep Yasa Yaman, "Siyasi/Estetik Gösterge” olarak Kamusal Alanda Anıt ve Heykel”, METU JFA, 28:1 (2011/1), 82.

11 http://www.sanalmuze.org/paneller/Mtskm/09sh.htm (Erişim tarihi 22 Nisan 2017); Adnan Çoker, "Soyut heykel”, Boyut 1/8 (1982), 4-6; Bakınız, Yasa Yaman, "Siyasi/Estetik Gösterge” olarak Kamusal Alanda Anıt ve Heykel” 82-83; Türkiye'deki Grup Espas için detaylı bilgiye bakınız, Ezgi Yavuz, "Designing The Ünity: Türk Grup Espas and Architecture in Postwar Turkey, METU JFA 32:2 (2015/2), 117.

12 Sanatçının 1971 yılında T.C. Lizbon Büyükelçiliği binası ve 1972 yılında İstanbul Eski Ticaret Odası Binası için yaptığı soyut rölyefleri bu tarz çalışmalarına örnek olarak verilebilir. 
yalarla sanatla tasarımı birleştiren Çalık; atölyede iskemle, koltuk, masa, kitaplık v.b. mobilyalar yaparak içmimarlık ve kişiye özel tasarımlarla İstanbul'a yeni bir iş kolu yaratmıştır ${ }^{13}$.

\section{Eskişehir’e Atatürk Anıtı talebi, Sakarya Gazetesi ve Yılmaz Büyükerşen}

1950'li yıllarda Eskişehir'in yerel gazetelerinden biri olan Sakarya gazetesinde birkaç ay arayla yayınlanan yazılarda halk, sivil toplum kuruluşları, öğrencilerin yaptıkları protestolar ve Atatürk anıtı istekleri doğrultusunda yapılan girişimler farklı haberlere konu olmuştur. Bu haberlerden ilki 18 Şubat 1959 tarihli Ahmet Aras'ın “İş ve İşçi Alemi” başlıklı köşesinde “Atatürk heykeli ne oldu?” başlıklı yazıdır. Bu yazıda 1953 yılında Eskişehir' de yapılan sendikalar toplantısında Vilayet Meydanı'na Atatürk heykeli yapılması kararına varıldı̆̆ı, ancak, aradan oldukça uzun bir süre geçtiği halde heykelin hala neden yapılmadığı anlatılmaktadır ${ }^{14}$. 25 Mayıs 1963 tarihli Sakarya gazetesinde Atatürk Stadı açılışı ile yapılan haberlerin hemen altında Atatürk heykeli için de bir haber yapıldığı görülmektedir. Bu haberde Sakarya İşçi Federasyonu'nun Atatürk'e ve İnkılabına gönülden bağlı oldukları belirtilmiş, Avukat Tahsin Atakan ile Belediye Başkanı Hicri Sezen'in anıt için İstanbul'a gittikleri anlatılmıştır ${ }^{15}$. Bu yazı yanında Sakarya gazetesinde çıkan farklı yazılarda Eskişehir'e Atatürk heykeli yapılması için toplantılar ve mitingler yapıldığı yazılmıştır. Bu yazılardan biri olan "Akademililer bir miting yaptılar -Gençler Atatürk Büstünü Vilayet önünde muvakkat bir kaideye diktiler" başlıklı yazı ilk sayfada yer almıştır ${ }^{16} \mathrm{Bu}$ haberler dışında "9 Temmuzda Şehrimizde Büyük Bir Meydan Toplantısı yapılacak Akademi öğrencilerinin yapacağı toplantıda Eskişehir için derhâl bir Atatürk heykeli istenecek" başlığı yapılmış, toplantıda Akademi hocalarından Prof. Dr. Tarık Zafer Tunaya, Doç. Dr. İsmet Giritli ve Behçet Kemal Çağlar'1n da birer konuşma yapacağı yazılmıştır ${ }^{17}$.

Öğrencilik yıllarından itibaren siyaset ve sanatın içinde yer alan Prof. Dr. Yılmaz Büyükerşen bu yıllarda kentte dolaşan dedikodular yüzünden 1959 yılına kadar Atatürk heykeli yapılmadığını, heykelin yapılmasını isteyen öğrenciler ile Eskişehirlilerin neler yaşadıklarını ve yaptıklarını kendi anılarında anlatmıştır ${ }^{18}$. Kente Atatürk heykeli

13 Çalık, Şadi Çalık, 44, Gökhan Karakuş, "Kare Metal”, Erken Cumhuriyet Döneminde Mobilya. Der. Umut Şumnu. 1 Bask1, (İstanbul: Ada Ofset, 2013), 115-118; Gezer ve Berk, 50. Yılın Türk Resim ve Heykeli, 146.

14 Ahmet Aras, "İş ve İşçi Alemi”, Sakarya, 18 Şubat 1959, 1.

15 “Atatürk heykeli için İstanbul'a giden heyet şehrimize döndü”, Sakarya, 25 Mayıs 1963, 1.

16 Cemalettin N. Taşçı, Yılmaz Büyükerşen Zamanı Durduran Saat. (İstanbul: Doğan Yayıncılık, 2009), 154; "Akademililer bir miting yaptılar. Gençler Atatürk Büstünü Vilayet önünde muvakkat bir kaideye diktiler", Sakarya, 21 Aralik 1959, s.1.

17 Taşç1, Yılmaz Büyükerşen, Zamanı Durduran Saat, 152-153; “9 Temmuzda Şehrimizde Büyük Bir Meydan Toplantısı Yapılacak Akademi öğrencilerinin yapacağı toplantıda Eskişehir için derhal bir Atatürk Heykeli istenecek", Sakarya, 5 Temmuz 1960, 1.

18 Taşçı, Yılmaz Büyükerşen, Zamanı Durduran Saat, 152-153. 
yapılmasını isteyen isimlerden biri olan Yılmaz Büyükerşen anılarında öğrenci olarak Erkek Sanat Okulu'nda dökülen Atatürk büstünü Valilik basamaklarına koyduklarını, "Eskişehir'e Atatürk anttı istiyoruz, Atatürk heykeli istiyoruz" şeklindeki dövizleri büstün iki yanına bıraktıklarını şöyle anlatmıştır: ${ }^{19}$

“...Eskişehir'e Atatürk anıtı istiyoruz, Atatürk heykeli istiyoruz şeklindeki dövizleri büstün iki yanına bıraktık. Vali, yardımcıları ve daire müdürleriyle protokol kapısının üstündeki geniş balkona çıkarak bizi izlemeye başladı. Ben bir konuşma yaparak, "Bu büst Eskişehir'e yaraşır, büyük bir anıt yapılıncaya kadar burada kalacak ve hiç kimsenin bunu kaldırmasına müsaade etmeyeceğiz. Bu geceden itibaren yanında sabaha kadar nöbet tutacă̆ım" dedim" diye anlatmıştır ${ }^{20}$.

Dönemin valisi İhsan Özalp de yaşanan bu olayın ardından kente Atatürk'e layık bir anıt yapılması için girişimleri başlattığını 22 Aralık 1959 tarihli Sakarya gazetesinde duyurmuştur. Atatürk anıtı için kurulan derneğin sekreterliğini üstlenen Yılmaz Büyükerşen Akademi gençliğinin temsilcisi olarak bu olaydan sonra çalışmaya başlamış, anıt için halktan yardım ve bağış toplanarak heykel için bir yarışma düzenlendiğini anılarında anlatmışı ır ${ }^{21}$. Atatürk heykeli için başlatılan çabalar doğrultusunda başvuran projeler arasından heykeltıraş Şadi Çalık'ın tasarladığı anıt seçilmiştir.

Sakarya gazetesinde Atatürk anıtının yapılışı, para toplanması ve açılışı hakkında pek çok haber bulunmaktadır. 15 Ağustos 1962 tarihli gazete de Atatürk Anıtı'nın Eskişehir'in düşman işgalinden kurtuluş tarihi olan 2 Eylül gününe yetiştirileceği anlatılmıştır (G. 1). Aynı yazıda Atatürk Anıtı Yaptırma Derneği tarafından geçen yıl temelleri atılan anıtın aralıksız çalışmalar sonunda bitirildiği, mermer rölyeflerin tamamlandığı ve montesine başlandığı, İstanbul'da hazırlanan tunç Atatürk heykelinin Eylül ayında Eskişehir'e getirileceği yazılmıştır ${ }^{22}$. 16 Ağustos 1962 tarihli gazetede anıtın bitirilmesi için 150 bin liraya ihtiyaç duyulduğu, yarım milyon liraya mal olacak olan anıtın 350 bin lirasının Anıt Yaptırma Derneği tarafından Vilayet, Belediye ve resmi müesseselerin yardımı ile sağlandığı belirtilmiştir (G. 2). Aynı gazetede:

“Montesine başlanan heykel şimdiye kadar Türkiye'de olmayan bir stil ve janra dayanarak yapılmıştır. "Anıt Yaptırma Derneği yöneticilerinden Abdurrahman Ünügör

19 Anılarda bahsedilen Atatürk büstünün Eskişehir anıtı bittikten sonra farklı yerlere konulması da farklı zamanlarda gazeteye haber olmuştur. "Kurslar Binasının Arka Bahçesine Akademi Gençlerinin Koyduğu Büst Dün Açıldı”, Sakarya, 24 Kasım 1962 1; “İ.T.İ. Akademisinin Vilayetin önüne koymuş olduğu büst tören ile tekrar geri verildi." Sakarya, 1 Ekim 1962, 1'deki yazıda bundan bir buçuk y1l önce Akademi gençliği tarafından vilayet önüne koyulan Atatürk büstü, Atatürk Anıtı tamamlandığı için Akademiye törenle geri verilmiştir. Törende Akademinin Dekanı Orhan Oğuz’un bir konuşma yaptığı ve büstün teslim alındığı yazılmıştır. Olasılıkla bu büst bugün Hukuk Fakültesi içinde yer alan büst olmalıdır.

20 Taşçı, Yılmaz Büyükerşen, Zamanı Durduran Saat, 154-155; “Akademililer bir miting yaptılar. Gençler Atatürk Büstünü Vilayet önünde muvakkat bir kaideye diktiler”, s.1.

21 Taşçı, Yılmaz Büyükerşen, Zamanı Durduran Saat, 156.

22 “Atatürk Anıt1 2 Eylül Günü Törenle Açılıyor”, Sakarya, 15 Ağustos 1962, 1. 
gazeteciler cemiyetinde yaptığ konuşmada “Anıt tamamlanmıştır. Borçlu kaldığımız miktarın temini de anitta hisse sahibi olmak isteyen Atatürkçü Eskişehirlilere düşmektedir ${ }^{23}$." demiştir.

17 Ağustos 1962 tarihli Sakarya gazetesinde "Eskişehir Gazeteciler Cemiyeti ve Sendikası Bildirisi: Atatürk Anıtına Yardım. Basın Mensupları Eskişehirlileri Atatürk Anıtına Yardım için Elbirliğine çă̆ırdı" başlığı ile yayınlanan yazıda Eskişehirlilerden anıta yardım etmeleri istenmiştir. Başta Vali ve Belediye Başkanı İhsan Özalp olmak üzere bazı müteşebbis ve idealist vatandaşlarımızın önderliği ile kurulan Atatürk Anıtı Yaptırma Derneği sayesinde anıtın büyük bir kısmının yapıldı̆̆ 1 ama tamamlamak için yardıma ihtiyaç olduğu yazılırken beğenilmeyen seren direği içinde haber yapıllmıştır ${ }^{24}$ (G. 3). 3 Eylül 1962'de “Atatürk Anıtına Halkın Yardımı Bekleniyor” başlıklı yazıda 100 bin liraya ihtiyaç olduğu, 500.000 liraya mal olan anıtın vilayet, belediye ve birkaç resmi teşekkülün verdiği teberrularla karşılandığı, derneğin heykeltıraşa 100 bin liraya yakın bir borcu olduğu, şimdiye kadar hemşerilerden yardım talep etmeyen derneğin yardım istediği, toplanan parayla meydanın tanzim edileceği bildirilmiştir ${ }^{25}$

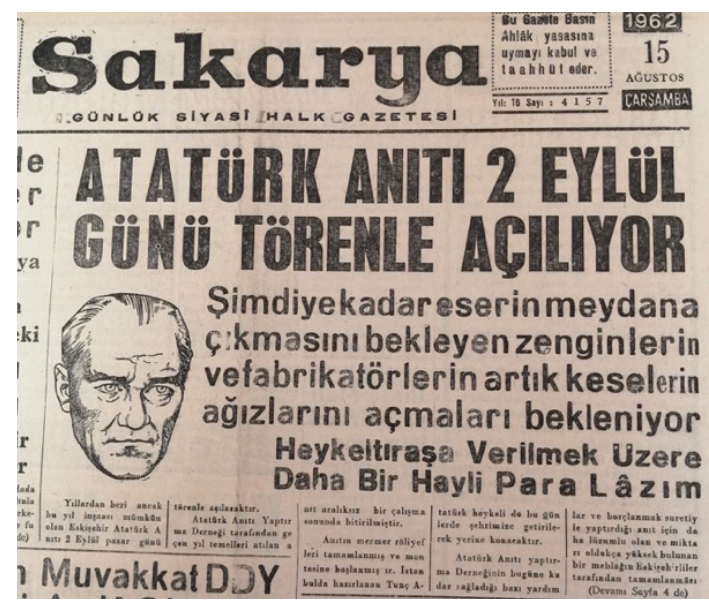

G. 1: 15 Ağustos 1962 tarihli Sakarya gazetesi (Selda Alp, 2020).

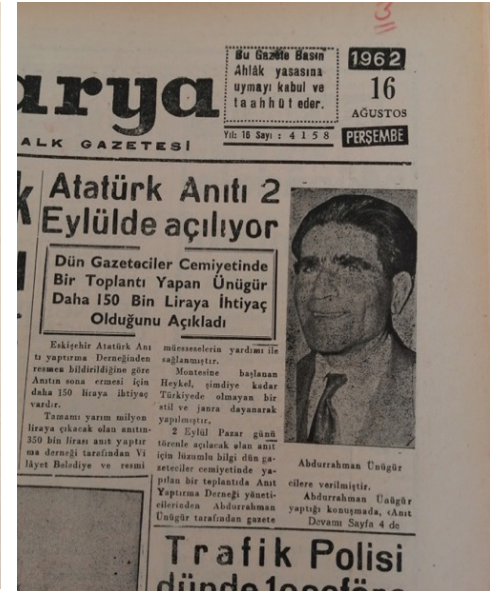

G. 2: 16 Ağustos 1962 tarihli Sakarya gazetesi (Selda Alp, 2020).

23 “Atatürk Anıtı 2 Eylülde açılıyor”, Sakarya, 16 Ağustos 1962, 4.

24 “Atatürk Anıtına Dikilecek Serenin Değişmesi İsteniyor”, Sakarya, 1 Eylül 1962, 1.

25 “Atatürk Anıtına Halkın Yardımı Bekleniyor”, Sakarya, 3 Eylül 1962, 1, 4. 


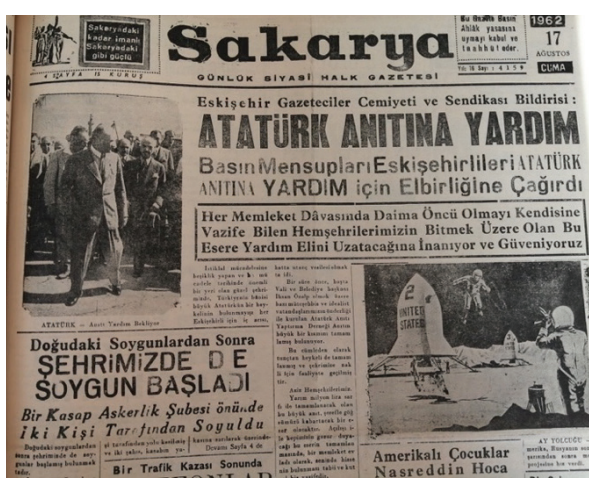

G. 3: 17 A ğustos 1962 tarihli Sakarya gazetesi (Selda Alp, 2020).

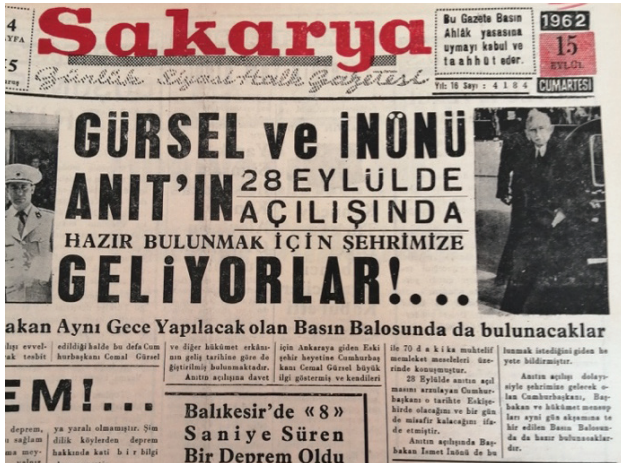

G. 4: 15 Eylül 1962 tarihli Sakarya gazetesi (Selda Alp, 2020).

5 Eylül 1962 tarihli Sakarya gazetesinde "Türk- İş Atatürk Anıtı için Kampanya Açtı. Bu münasebetle bir bildiri yayınladı" başlıklı yazıda Türk-Işs ikinci bölge temsilciliği Eskişehir'deki diğer sendikalar ile 3 Eylül 1962 akşamı bir toplantı yaptığı, bu toplantıda işçilerin Atatürk anıtı için işyerlerinde topladıkları parayla yardıma katıldıkları, ama toplanan paranın kâfi gelmediği yazılmıştır. Toplantıya DDY; Şeker, Tayyare, Toprak Sanayii, Çimento, Karayolları Genel-İş, Oleyiş, Esum İş ve Yapı İşçileri Sendikasının katıldığı bildirilmiştir ${ }^{26}$. Bu toplantıda işçilerden yeniden yardım talep edilmiştir:

“IŞÇİ ARKADAŞ: Eskişehir'de büyük Atatürk'ün bir anıtının bulunmamast yıllardan beri, sendika kongrelerimizde önemli yer almakta idi. Hatta 22 Şubat 1953 günü yapılan büyük miting 'te Türk işçisi olarak Eskişehirde Atatürk Anıtının yapılmasına teşebbüs edilen anıt nihayet sayın Valimizin azimli gayretleri gerçekleşmiş bulunmaktadır’. ${ }^{27}$

15 Eylül 1962 tarihli Sakarya gazetesinin ana başlığında “Gürsel ve İnönü Antt'ın 28 Eylülde açıllı̧ıında hazır bulunma için şehrimize geliyorlar!..."28; 28 Eylül 1962 tarihli "Atatürk Anıtına Kavuştuk Sevincimiz Çok Büyük. Bugün Saat 15 de Anıt Cumhurbaşkanı Tarafindan Törenle Açılacak”, gibi yazılarda Atatürk anıtı ile ilgili farklı haberler yapılarak Atatürk Anıtı gündemde tutulmuş, destek istenmiş ve açılış programı yayınlanmıştır (G. 4, G. 5).

26 "Türk-İş Atatürk Anıtı İçin Kampanya Açtı. Bu münasebetle bir bildiri yayınladı", Sakarya, 5 Eylül 1962, 1.

27 "Türk-İş Atatürk Anıtı İçin Kampanya Açtı. Bu münasebetle bir bildiri yayınladı", 4.

28 “Gürsel ve İnönü Anıt'ın 28 Eylülde açılışında hazır bulunma için şehrimize geliyorlar!., Sakarya, 15 Eylül 1962, 1; "Atatürk Anıtına Kavuşuyor Sevincimiz Çok Büyük. Bugün Saat 15 de Anıt Cumhurbaşkanı Tarafindan Törenle Açılacak”, Sakarya, 28 Eylül 1962, 1. 


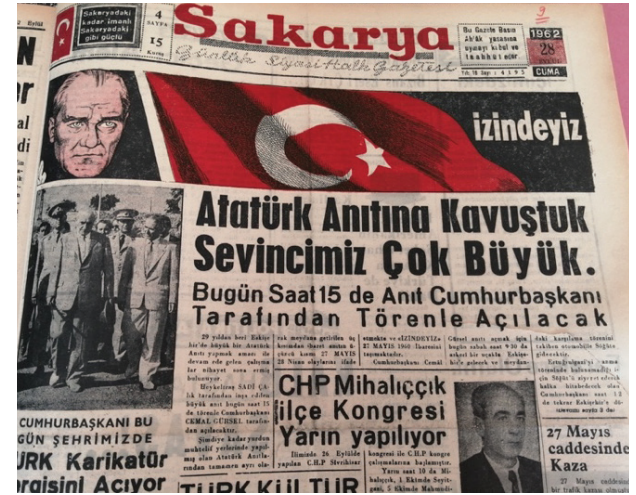

G. 5: 28 Eylül 1962 tarihli Sakarya gazetesi

(Selda Alp, 2020).

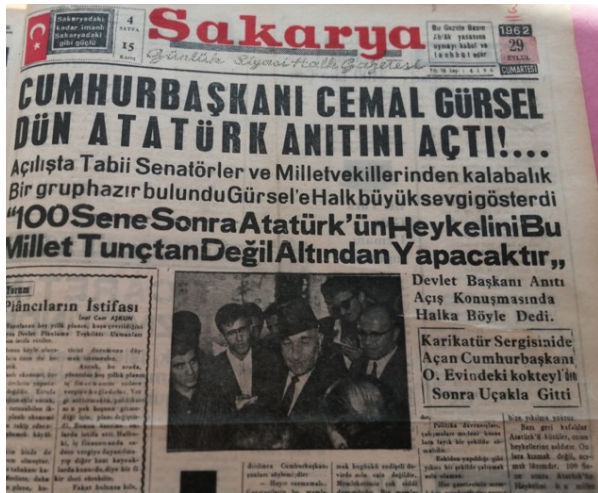

G. 6: 29 Eylül 1962 tarihli Sakarya gazetesi (Selda Alp, 2020).

Anıtın açılış günü ertesinde 29 Eylül 1962 Cumartesi günü basılan Sakarya gazetesinin tüm sayfaları neredeyse Atatürk anıtına ayrılmış, ana haberlerde ve köşe yazılarında Atatürk ve anıtla ilgili övgüler yapılarak kent insanın ne denli mutlu olduğu gösterilmiştir. “Cumhurbaşkanı Cemal Gürsel Dün Atatürk Anıtını Açtı!.. haberinde 29 yıldan beri Eskişehir'de büyük bir Atatürk anıtı yapmak için çalışmaları nihayet sona ermiş bulunuyor, anıtın heykeltıraşın Sadi Çalık olduğu yazılmıştır ${ }^{29}$. Yazıda ayrıca şu bilgi verilmiştir:

“(...) Şimdiye kadar yurdun muhtelif yerlerinde yapılmış Atatürk anıtlarından tamamen ayrı olarak meydana getirilen üç kısımdan ibaret anıtın üçüncü kısmı 27 Mayıs ve 28 Nisan olaylarını ifade etmekte ve "İzindeyiz" 27 Mayıs 1960 ibaresini taşımaktadır". ${ }^{30}$

29 Eylül 1962 tarihli gazetede Prof. Dr. İnal Cem Aşkun’un “Anıt Açılırken”, M. Ergin'in "İzindeyiz" yazıları ile Hilmi Çıngıroğlu’nun “Anıtın Iç̧in” başlıklı şiiri Eskişehir’i Atatürk anıtı gibi kültür eserleriyle süslememiz gerektiği anlatılmış, açılışın herkesi heyecanlandıran ve mutlu eden bir görev üstlendiği gösterilmiştir ${ }^{31}$. Aynı gazetede anıtın açılışında Cumhurbaşkanı Cemal Gürsel'in yaptığı konuşmadan alıntılar büyük olarak yazılmıştır. Gürsel "100 sene sonra Atatürk'ün heykelini bu millet tunçtan değil altından yapacaktır” demiştir (G. 6). Cumhurbaşkanı'nın ardından Atatürk Anıtı Yaptırma Derneği Başkanı Abdurrahman Ünügör anıt ve maliyeti hakkında yaptığı konuşması ile halka açıklamalarda bulunmuştur. Ünügör anıtın bir yılda tamamlandığını, üç kısımdan meydana geldiğini, Atatürk heykelinin 4 m olduğunu, anıtın ilk mali portresinin 600.000 lira olarak tespit edildiğini, kaba inşaat için müteahhite 100.000 lira, Heykeltıraş Sadi Çalık’a 350.000 lira ayrıldığını, şimdiye kadar yapılan masraflarla anıtın ortalama 500.000 liraya çıktığını, yakında hesapların teker

29 “Cumhurbaşkanı Cemal Gürsel Dün Atatürk Anıtını Açtı!..” Sakarya, 29 Eylül 1962, 1.

30 "Cumhurbaşkanı Cemal Gürsel Dün Atatürk Anıtını Açtı!..” Sakarya, 29 Eylül 1962, 1.

31 İnal Cem Aşkun, “Anıt Açılırken”, Sakarya, 29 Eylül 1962, 1; M. Ergin, “İzindeyiz”, Sakarya, 29 Eylül 1962, 1 'deki yazıları dönem insanının Atatürk anıtlarına bakışını ve titizliğini göstermektedir. 
teker açıklanacağını belirterek, anıtın yapılmasına yardım edenlere ayrı ayrı teşekkür etmiştir. Bu konuşmanın ardından yüksek öğrenim gençliğini ithafen Sevgi Kalyoncuoğlu ve Yılmaz Büyükerşen'in konuşma yaptığı yazılmıştır. Açılışta da öğrenci olarak görev alan Yılmaz Büyükerşen heykelin önünde Atatürk gençliği adına hayatının en heyecanlı ve gururlu konuşmasını yaptığını anılarında da anlatmıştır ${ }^{32} .1962$ yılında Eskişehir'de Atatürk ve Gençlik Anıtı için açılan yarışmada heykeltıraş Ali Hadi Bara, mimar Ahsen Yapanar ve Nezih Eldem'in yer aldığ jüri tarafından birinci seçilen Çalık, anıtı İstanbul'daki Plaj yolundaki atölyesinde tamamlamıştır. Sanatçının kızı Siren Çalık tarafından yazılan kitapta anıtın 29 Ekim'de açıldığı belirtilse de yukarıda da anlatıldığı gibi, anıt 28 Eylül 1962 tarihinde saat 15.00’te dönemin Cumhurbaşkanı Cemal Gürsel'in katıldığı bir törenle açılmıştır ${ }^{33}$.

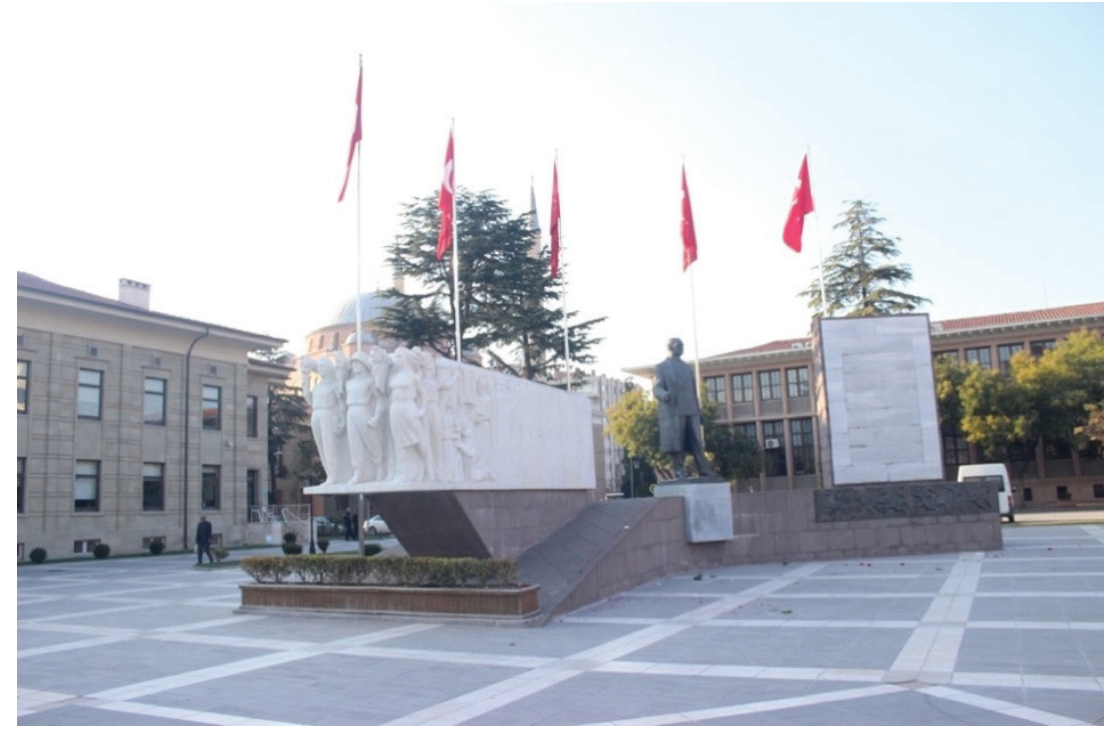

G. 7: Eskişehir Valilik Meydanı Atatürk ve Gençlik Anıtı (Selda Alp, 2020).

32 Taşçı, Yılmaz Büyükerşen, Zamanı Durduran Saat, 157.

33 Çalık, Şadi Çalık, 47; “Gürsel ve İnönü Anıt'ın 28 Eylül'de açılışında hazır bulunma için şehrimize geliyorlar!..”, Sakarya, 15 Eylül 1962, 1, "Atatürk Anıtına Kavuşacak Sevincimiz Çok Büyük. Bugün Saat 15 de Anıt Cumhurbaşkanı Tarafından Törenle Açılacak”, Sakarya, 28 Eylül 1962, 1; Aşkun “Anıt Açılırken”, 1; Ergin, "İzindeyiz”, 1; "Eskişehir Atatürk Anıtı Açılış Töreni Programı, Sakarya, 27 Eylül 1962, 3. 


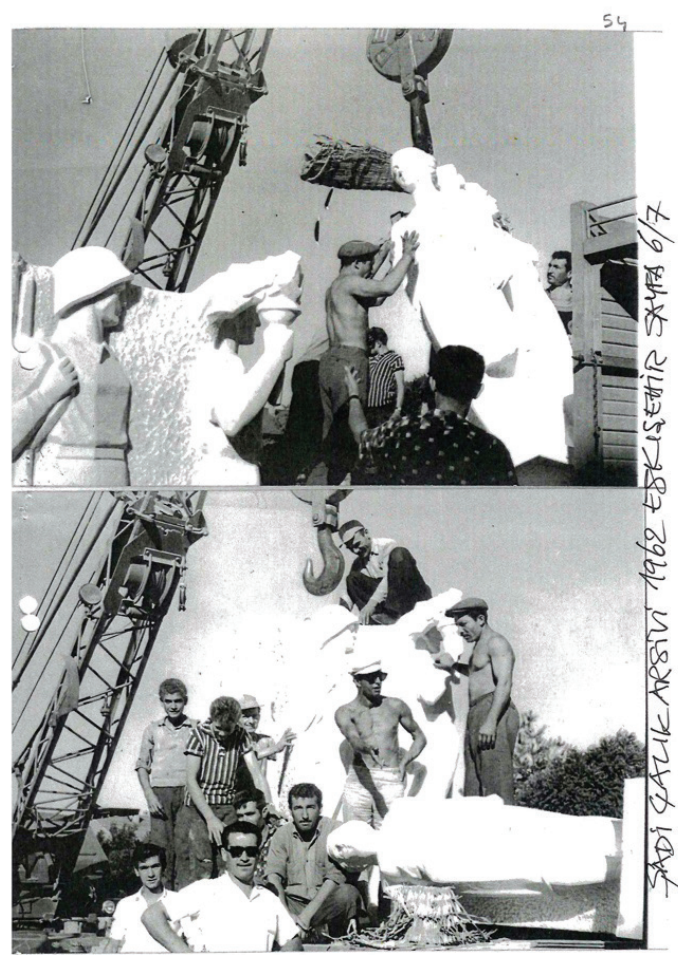

G. 8: Anıtın yapımı sırasında heykeltıraş Şadi Çalık işçilerle birlikte, 1962 (T.C. Kültür Bakanlığı Eskişehir Kültür Varlıkları Koruma Bölge Müdürlüğü arşivi)

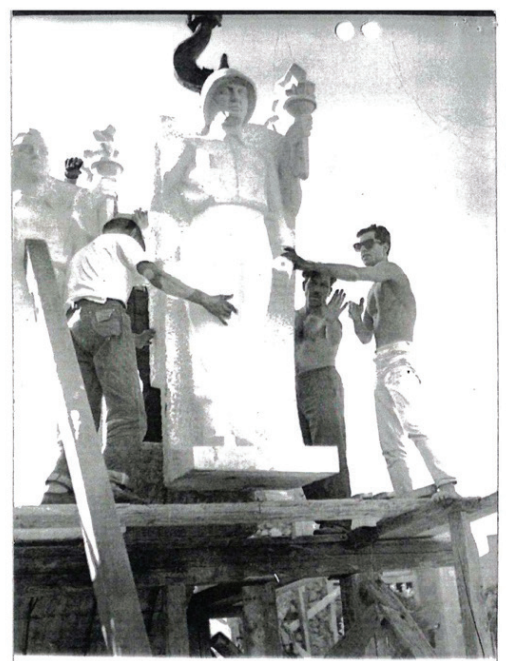

AADI GAUK KRS, IVI

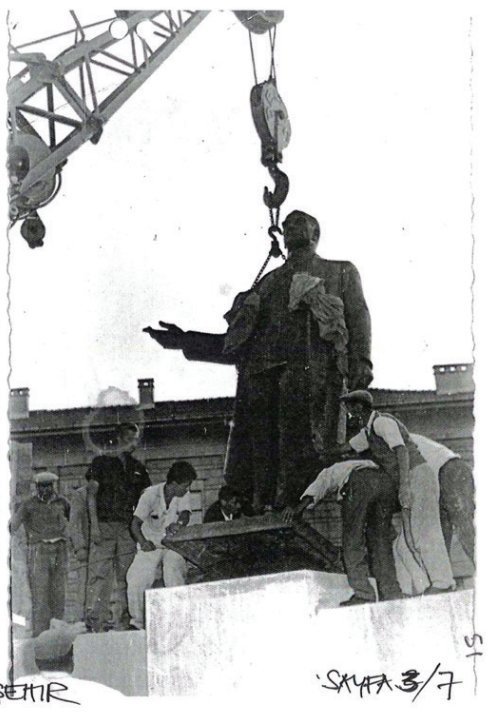

G. 9: Anıtın yapımı sırasında heykeltıraş Şadi Çalık işçilerle birlikte, 1962 (T.C. Kültür Bakanlığı Eskişehir Kültür Varlıkları Koruma Bölge Müdürlüğü arşivi) 
Anıtın açılışı ile ilgili yapılan Sakarya gazetesi haberlerinde dönemin Cumhurbaşkanı Cemal Gürsel'in ve dönemin Milli Birlik Komitesi üyelerinin Eskişehir'e geldiğini yazılmıştır ${ }^{34}$. Valilik Binası önündeki merasim alanı içinde yer alan anıtta, ortada "Atatürk" heykeli, sağda "Türk Gençliği Figürleri”, solda "Atatürk'ün Gençliğe Hitabesi" yazılı metin bloğu ve kaide kabartmaları bulunmaktadır. Anıtın açılışı yapılmadan bir gün önce kentin öğrencileri tören alanında meşaleler yakarak nöbet tutarak Ata'ya saygılarını göstermişlerdir. Eskişehir Atatürk ve Gençlik Anıtı 28 Eylül 1962 tarihinde Atatürk gençliğine ve Eskişehir halkına yakışır biçimde açılmıştır (G. 7, G. 8, G. 9).

\section{Atatürk ve Gençlik Anıtı}

Anit Cumhuriyetin ilanından sonra yapılan ilk anıtlardan biri olmasa da anıtsal boyutları ve rampa düzenlemesiyle farklı bir örnektir. Rampa ve kaidede andezit kaplama, anıtta mermer kaplama kullanılmıştır. Atatürk heykeli bronz malzeme ile yapılırken, kare kübik kaidesi gri-yeşil mermerdendir. $1.88 \mathrm{~cm}$ yüksekliğindeki rampanın bitişinde orta noktada yer alan Atatürk tüm meydanı kucaklar biçimdedir. $3.60 \mathrm{~cm}$ yüksekliğindeki heykelde sivil kıyafetle betimlenen Atatürk üzerindeki takım elbise ve uzun paltosuyla oldukça heybetlidir. Paltosunun önü açı, içindeki takım elbisenin tüm detayları tasvir edilmiştir. Takım elbisesinin düğmeleri kapalı, dik yakalı gömleği kravatlıdır. Ceketin üç düğmesi vurgulanırken, göğsü öne doğru çıkık olarak dimdik durmaktadır. Paltosu omuzlarının iki yanına doğru kaydırılmış, yandan kıvrımlı olarak betimlenmiştir. Paltonun cepleri, yakası, omuzları çizgisel bir anlayışla işlenmiştir. Ayakta ve başı dik olarak karşıya bakan Atatürk sağ elini dirsekten hafif olarak bükmüş, işaret parmağı ile sağ yönü göstermektedir. Sol kolu yere paralel biçimde aşağıya doğru serbest olarak bırakılırken, avuç içi ise sol bacağına dönüktür. Atatürk'ün elleri sanatçının diğer heykellerinde olduğu gibi uzun ince kemikli parmaklıdır. Sol elinin küçük ve yüzük parmakları başparmakla birleşir gibi diğer parmakları da hafif içe doğrudur. Sağ el ise işaret parmağı uzatılmış, diğer parmakları da avuç içine doğru kıvrılmıştır. Sol ayağı sabit sağ ayağı ise hafif kıvrılmış bir kontrapost duruşla betimlenmiştir. Sol ayak sağ ayağından bir adım önde ve adım atacak biçimdedir. Sol ayağın önde olması heykele hareket kazandırırken göğsün öne doğru duruşuna da destek olmaktadır. Atanın yüzündeki ifadede güç, irade ve önderlik vasıfları vurgulanmıştır. Alın ve şakakları açık, saçları geriye doğru taranmıştır. Gür kaşları hafif çatık biçimdedir. Kaşları arasındaki ve alındaki kırışıklar görülmektedir. Badem biçimli gözleri tam karşıya bakmaktadır. Düzgün burnu kaşları arasından başlayarak dudak üzerine kadar oranlı biçimde işlenmiştir. İnce dudakları kapalıdır. Yüzde vurgulanan ifade gözlerdedir. Kaidede sanatçının ve döküm ustasının kitabesi bulunmaktadır. Kaidenin sağında "HEYKELTIRAŞ M. ŞADİ ÇALIK"; solunda ise "DÖKEN M. YETKİNER

34 “Cumhurbaşkanı Cemal Gürsel Dün Atatürk Anıtını Açtı!..”, Sakarya, 29 Eylül 1962, 1. 
NAZILLLI" yazılıdır (G. 10, G. 11, G. 12). Atatürk heykelinin sağında kadın ve erkek figürleriyle "Türk Gençliği Figürleri” solunda ise "Atatürk'ün Gençliğe Hitabesi" yazılı blok yer alır. Atatürk'ün sağ eliyle gösterdiği bölümde yer alan figürlü heykel grubunda Türk gençliği anlatılmaktadır.

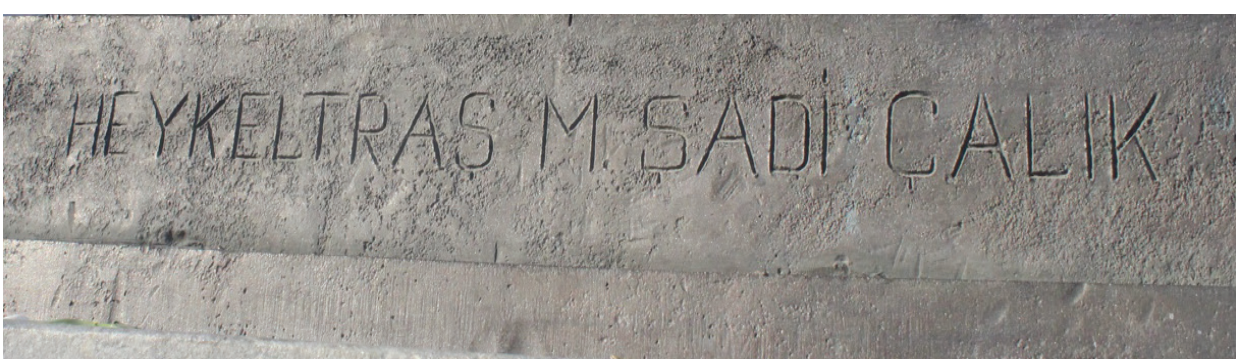

G. 10: Atatürk heykelinin kaidesindeki sanatçı kitabesi. "Heykeltraş M. Şadi Çalık” yazısı (Selda Alp, 2020).
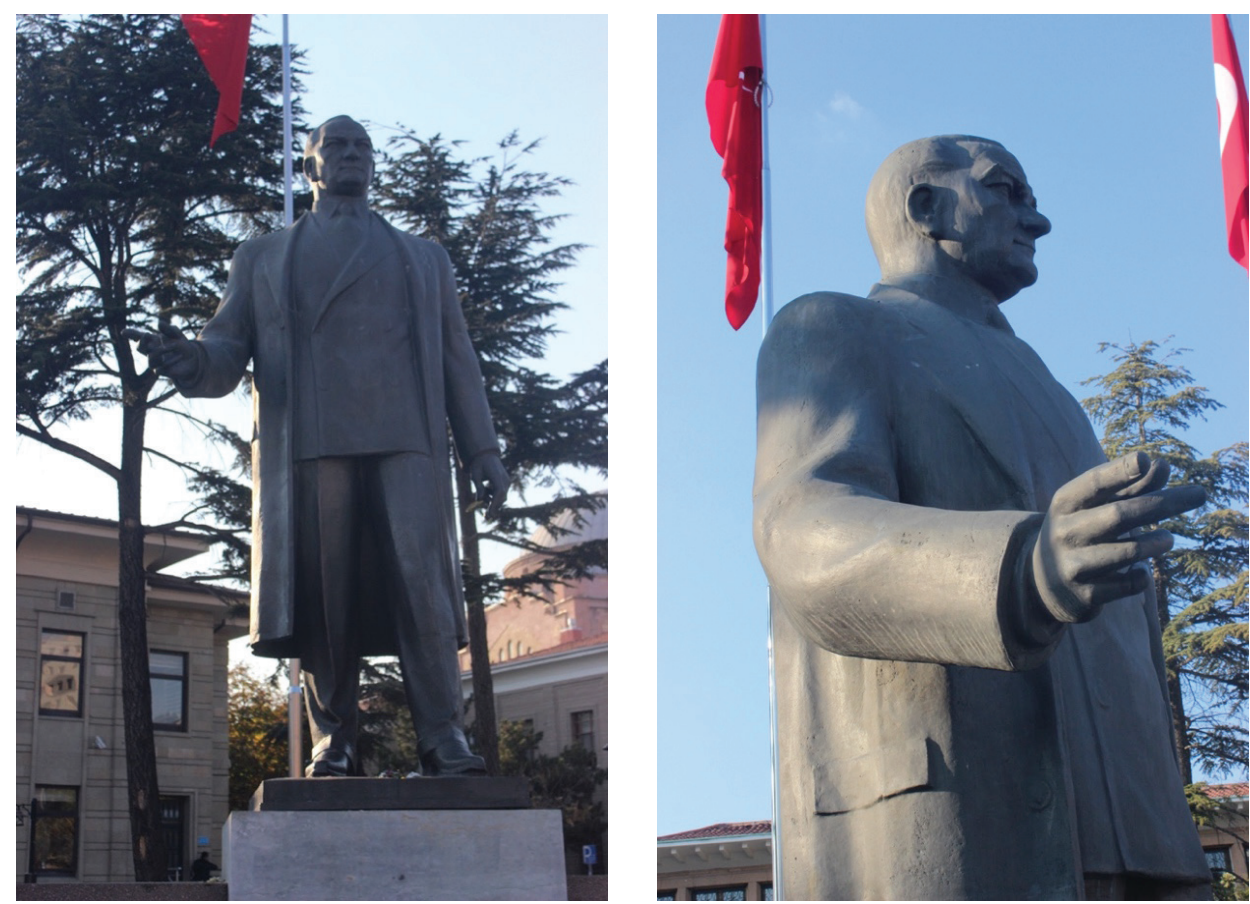

G. 11 ve G. 12: Atatürk heykeli. (Selda Alp, 2020)

Rampaların ortasına yerleştirilen heykeller $1.88 \mathrm{~cm}$ yüksekliğindeki alt kaide üzerindedir. Rampaların tersi yönündeki heykel kaidesi üzerindeki heykellerin $25 \mathrm{~cm}$ 'lik masif kaideleriyle birlikte tasarlandığ 1 , yaklaşık yüksekliklerinin $1.87 \mathrm{~cm}$ olduğu 
görülmektedir. Kaideyle birlikte anıtın toplam yüksekliği 4.00 metredir. İlk sırada işlenen üç genç figürünün ellerinde meşaleler bulunmaktadır. Sağ ellerinde tuttukları yanan meşaleleri yukarıya doğru kaldıran gençlerin tümü güçlü duruşlarıyla betimlenmiştir. Figürlerden ikisi erkek biri kadındır. Sağdaki sivil kıyafetli erkek figürü sivil kıyafet ile betimlenirken, sağ elindeki meşale halkın direnişini sol elindeki kitap ise eğitilen gençlik ile kurulan Cumhuriyetin doğuşunu temsil etmektedir. Erkek figürünün sağ ayağ1 öne doğru, sol ayağı ise geriye doğrudur. Adım atar biçimde işlenmiştir. Üzerinde pantolon ve yakalı bir tişört giyen erkek figürü kendinden emin ve özgüveni yüksek biçimde tasvir edilmiştir. Ortadaki asker figürünün sağ ayağı öne doğru sol ayağ 1 ise geriye doğrudur. Üzerinde askeri üniforma bulunmaktadır. Pantolon ve gömleği çizgisel bir anlayışla anlatılmıştır. Bacaklar ve pantolonun dikey çizgileri figürün üzerindeki gömlekle kesilmiştir. Omuzları geniş ve diktir. Sağ elindeki meşale geleceğin aydınlık yüzünü sembolize ederken, başında Emniyet mensuplarının törende giydikleri miğfer şapka bulunmaktadır. Soldaki kadın figürü de diğer figürler gibi yürür biçimdedir. Sağ elinde yanan meşale taşırken, sol eli belindedir. Üzerinde yuvarlak yakalı bir tişört ve çan etek giydirilmiştir. Eteğinin uç kısımları hareketini destekler gibi uçuşmaktadır. Uzun saçları ensede büyük bir topuz oluşturacak biçimde toplanmıştır. Erkek figürleri gibi güçlü ve kuvvetli yeni Cumhuriyeti sembolize eden kadın figürünün sol ayağı geriye doğru, sağ ayağı ise dik olarak durmaktadır.

Gençlik heykel grubunun solunda yan kanatlarda/yüzeylerde de gençlik grubu figürleri ile devam ettirilmiş ve "izindeyiz" yazısı yazılmışıtır. Gençlik grubu heykelleriyle paralel biçimde devam ettirilen kabartmalarda da üçerli gruplar halinde kadın, erkek ve melek grubu işlenmiştir. Ön yüzde elinde meşale tutan dördüncü erkek heykeli "gençlik grubu heykellerini”" devam ettiren biçimde sağ elinde yanan meşale tutar biçimde sol elini ve ayağını yana doğru açar biçimde betimlenmiştir. Sağ eliyle kabartmaların levhalarına doğru hareketi devam ettirirken dalgalanan bayrağın yanında avuç içi çizgisel bir anlatımla vurgulanmıştır. Erkek figürünün devamında üçgen kompozisyon içine sıkıştırılan kadın, erkek ve melek figürleri dikkati çekmektedir.

Kadın ve erkek figürleri Türk gençliğinin yeni ve aydınlık yüzünü sembolize eder. Her ikisinin elleriyle tuttukları dalgalanan bayrak sonsuza dek var olacak olan Türkiye Cumhuriyeti'ni anlatır. Ön yüzde diz çöken kadın figürünün de sağ elinde yanan meşale diğer elinde ise bayrak direği tutar biçimde cepheden gösterilmiştir. Zemine oturan erkek figürü sol eliyle kadının tuttuğu meşaleyi tutarken sağ eliyle zeminden destek almaktadır. Erkek figürünün yanında ayakta duran kanatlı melek kabartması betimlenmiştir. Tek kanadı açı duran figürün başı haleli olarak diğer figürlerden ayrılmaktadır. Figürün üzerindeki uzun elbisenin etek kısmı boyuna çizgilerle tasvir edilmiştir. Kısa saçları ve kusursuz yüz hatlarıyla idealize edilen meleğin elinde çelenk ile yeniden doğuşu sembolize etmektedir. Üç figürün ellerinde bulunan meşalebayrak-çelenk yeniden doğuşu hatırlatır. Melek kanatları çizgisel bir anlayışla belir- 
gindir. Kadın ve erkek bedenleri konstrüktivist biçimde güçlü kolları, köşeli bedenleri ile anlatılır. Yere oturan erkek figürünün sağ eli büyüktür. Parmakların zemini tutar biçimde kurgulanması sanatçının özelliğidir. "İZINDEYIZ" yazısı kabartma olarak yazılmıştır.

Mermer bloğun arka yüzü yazısızdır ve 7 levhadan oluşmaktadır. Arka blokta bulunan asker figürü tektir. Ön yüzdeki gençlik grubu heykelleriyle birlikte mermer bloğu içinde tasarlanan asker figürü omuzundaki silahıyla birlikte dimdik durmaktadır. Ön yüz ortadaki asker figürüyle aynı biçimdeki üniformasıyla çizgisel bir anlayışla betimlenmiştir. Sol ayak önde sağ ayak arkadadır. Pantolonu uzun postalları içine sokulmuştur. Pantolonun dikey çizgileri figürün belindeki yatay çizgiyle kesilmiştir. Dik yakalı gömleği, başındaki miğfer şapka ile Türk gençliğini sembolize eder.

Anıtın üçüncü bölümünde "Atatürk'ün Gençliğe Hitabesi” ve "Kurtuluş Savaşı" kabartmaları yer alır. Hitabenin yazıldığ $\mathrm{m}$ x $5 \mathrm{~m}$ boyutlarındaki duvar üzerine monte edilmiş beyaz mermer kaplamalardan oluşmaktadır. Gençliğe Hitabe mermerden kabartma olarak yazılmıştır. Hitabede kullanılan harfler 40 mm'lik harflerden oluşturulmuştur. Metin sekiz ayrı levha üzerine yazılmış, monte edilirken bir araya getirilmiştir. $50 \times 190 \mathrm{~cm}$ boyutlarındaki levhalara yazılı Gençliğe Hitabe'nin sonu sarmaşık motifiyle süslenmiştir. Hitabe 46x85 cm'lik 12 boş levhalarla çevrelenerek adeta bir kitap sayfasına dönüştürülmüştür.

“Atatürk'ün Gençliğe Hitabesi”sinin altında kaidenin ön ve arka yüzünde Kurtuluş Savaşı'nın anlatıldığ kabartmalar bulunmaktadır. Kabartmalar bronzdan yapılmıştır. Dokuz figürün betimlendiği kabartmalarda yedi asker, Atatürk ve Anadolu kadını bir aradadır. Soldan itibaren ilk iki figür atlıdır. Doludizgin atla ilerleyen figürler düşmana saldırı anında betimlenmiş asker figürleridir. Hızlı gidişlerinin ipuçlarını veren zeminde havalanmış taş parçaları havada uçuşmaktadır. Üç, dört ve beşinci figürler üçlü kompozisyon oluştururken ellerindeki silahların farklı biçimlerde tutulmaları ile dinamik ve hareketlidir. Altıncı figür Anadolu kadınıdır. Elinde şahlanan Türk bayrağı ile savaş alanında koşar biçimdedir. Şalvarı ve yuvarlak yakalı mintanı, uçuşan başörtüsüyle top namlusunun önünde yanında barışın sembolü olan zeytin dalı ile birliktedir. Yedinci figür Atatürk'tür. Top arabasının yanında Atatürk sağ eliyle "Ordular ilk hedefiniz Akdeniz'dir ileri" komutasını verirken gösterilmiştir. Üzerinde kaput giymiş olarak ayaktadır. Savaşın her anını kontrol eden bir kumandan olarak elinde dürbünü belinde silahıyla, uzun çizmeleriyle betimlenmiştir. Kalpaklıdır. Uzun bıyıkları ile kendinden emin zafer kazanacak bir komutan gibi durmaktadır. Yanında duran asker elindeki namluyu top arabasına koymaktadır. En sonda yer alan figür ise cepheden her an silah çekmeye hazır biçiminde gösterilmiştir. Kabartmada hareket ve dinamizm dikkati çekerken Atatürk ve sol köşedeki asker figürüyle hareket tersine çevrilmiştir. Kabartmada Atatürk'ün diğer figürlerden ayrı tutularak vurgulanması, 
Türkiye'de yapılan diğer Atatürk anıtlarıyla benzerdir. Eskişehir'deki “Atatürk ve Gençlik Anıtı"nda Atatürk'ün gençlerden umudu hem görsel olarak heykellerle hem de metin olarak "Gençliğe Hitabe" ile anlatılmıştır.

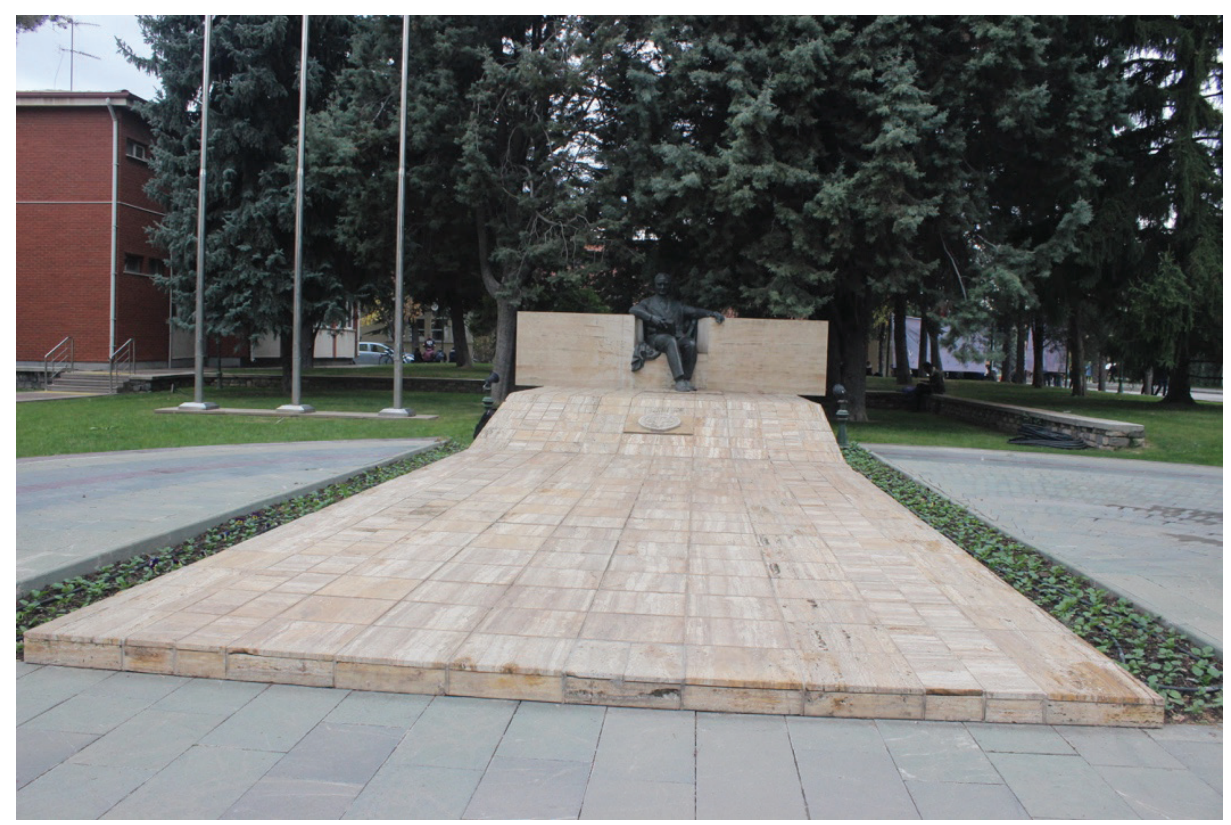

G. 13: Anadolu Üniversitesi Hukuk Fakültesi önündeki tören alanındaki Atatürk heykeli

(Selda Alp, 2020)

\section{Anadolu Üniversitesi Atatürk Anıtı}

Şadi Çalık yukarıda detaylı olarak anlatılan anıt dışında Anadolu Üniversitesi Yunus Emre Kampüsü Hukuk Fakültesi önünde yer alan tören alanındaki Atatürk anıtını da yapmıştır (G. 13). Heykelin açıldığı yıllarda Eskişehir İktisadi ve Ticari İlimler Akademisi olarak açılan okulun ilk yöneticisi Prof. Dr. Orhan Oğuz; yardımcısı ise Prof. Dr. Yılmaz Büyükerşen'dir. Anadolu Üniversitesi'nin temelini oluşturan Eskişehir İktisadi ve Ticari İlimler Akademisi’nin kurucusu olan Orhan Oğuz 1958-1969 yıllarında Akademi'de çalışmıştır. 1958 yılında Profesör olarak Eskişehir Akademisini kurmakla görevlendirilen Orhan Oğuz'un 11 yıl süren bu görevi sırasında kampüsün inşa faaliyetlerine önem vermiştir. Ne yazık ki Anadolu Üniversitesi’nin bir arşivi bulunmadığı için elimize geçen fotoğraflar ve sözlü tarih bilgileri heykelin 1969 yılında açıldığını düşündürmektedir. Siren, Çalık'ın kitabında 1970 tarihi verilse de heykel üzerinde tarih ve imza bulunmamaktadır. ${ }^{35}$

Heykelin yapıldığı yıllarda Akademi'nin yöneticilerinden biri olarak çalışan Prof. Dr. Fazıl Tekin hocamızla yaptığımız görüşmeye dayanarak; 21 Ekim 1968 tarihi olan Akademi’nin 
açılış tarihinden beş ya da altı ay sonra Atatürk heykelinin açılış töreni yapılmıştır. Net tarihi hatırlamayan hocamız açılışına bizzat katılmış ve Prof. Dr. Orhan Oğuz'un Akademi başkanı olduğu yıllarda açılışını doğrulamıştır. Üniversitenin heykellerinin fotoğraflarını bir kitapta toplayan Prof. Dr. Levend Kılıç ise heykelin 1971 yılında yapıldığını belirtmektedir. ${ }^{36}$ Kılıç'ın verdiği tarih Orhan Oğuz’un yönetimiyle örtüşmemektedir.

Anadolu Üniversitesi Çağdaş Sanatlar Müzesi koleksiyonunda Atatürk heykelinin günümüze ulaşan farklı boyutta hazırlanmış iki adet alçı maketi bulunmaktadır. $\mathrm{Bu}$

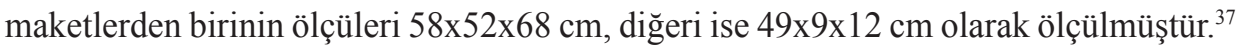
(G. 14, G. 15).

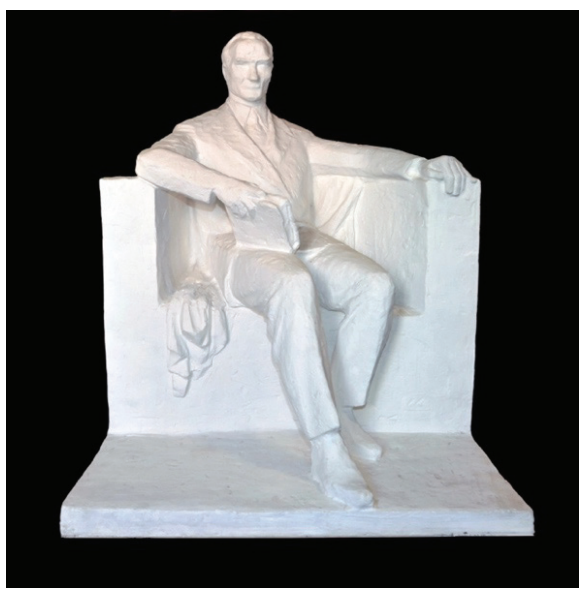

G. 14: Anadolu Üniversitesi Güzel Sanatlar Müzesi’nde bulunan Atatürk heykeli büyük maketi (Selda Alp, 2020)

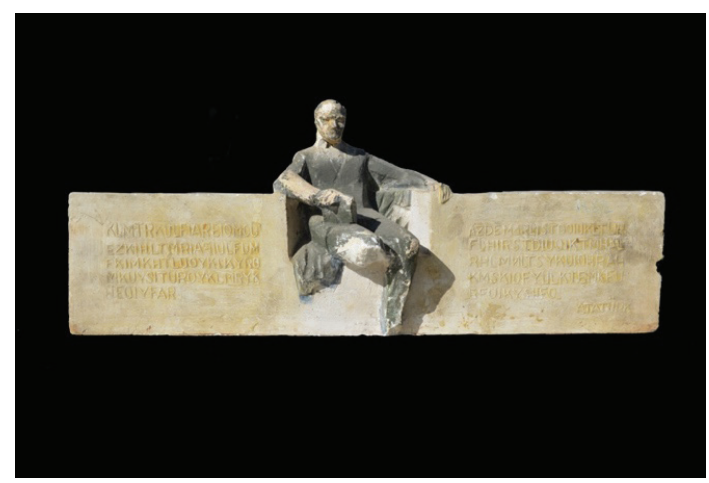

G. 15: Anadolu Üniversitesi Güzel Sanatlar Müzesi’nde bulunan Atatürk heykeli küçük maketi (Selda Alp, 2020)

36 Levend Kılıç, Heykellerle Yaşayan Üniversite, (Eskişehir: Anadolu Üniversitesi Yayınları, 2005), 14 ve 15 'te heykelin 1971 yılında sergilenmeye başladığını belirtmektedir.

37 Büyük makette zeminden Atatürk'ün oturtulduğu koltuk $43 \mathrm{~cm}$ yükseklikte, kafa yüksekliği ise $68 \mathrm{~cm}$ 'dir. Küçük maketin kaidenin genişliği $49 \mathrm{~cm}$, yüksekliği $9 \mathrm{~cm}$, Atatürk figürünün yüksekliği ise $12 \mathrm{~cm}$ 'dir. 
Boyut olarak büyük olan makette sadece heykel betimlenirken, küçük makette kaidenin iki yanına simetrik olarak kitabenin yazılacağı gösterilmiştir. Küçük makette rasgele harflerin anlamlı bir kelime oluşturmadığı görülmektedir. Sanatçı makete göre dört satırlık kitabe yazmayı planmış, bu maketleri Akademi'nin o yıllardaki Başkanı Prof. Dr. Orhan Oğuz ve yardımcısı Prof. Dr. Yılmaz Büyükerşen'e göstermiştir. Anıt maketteki gibi kaide kitabeleri olmadan bitirilmiştir.
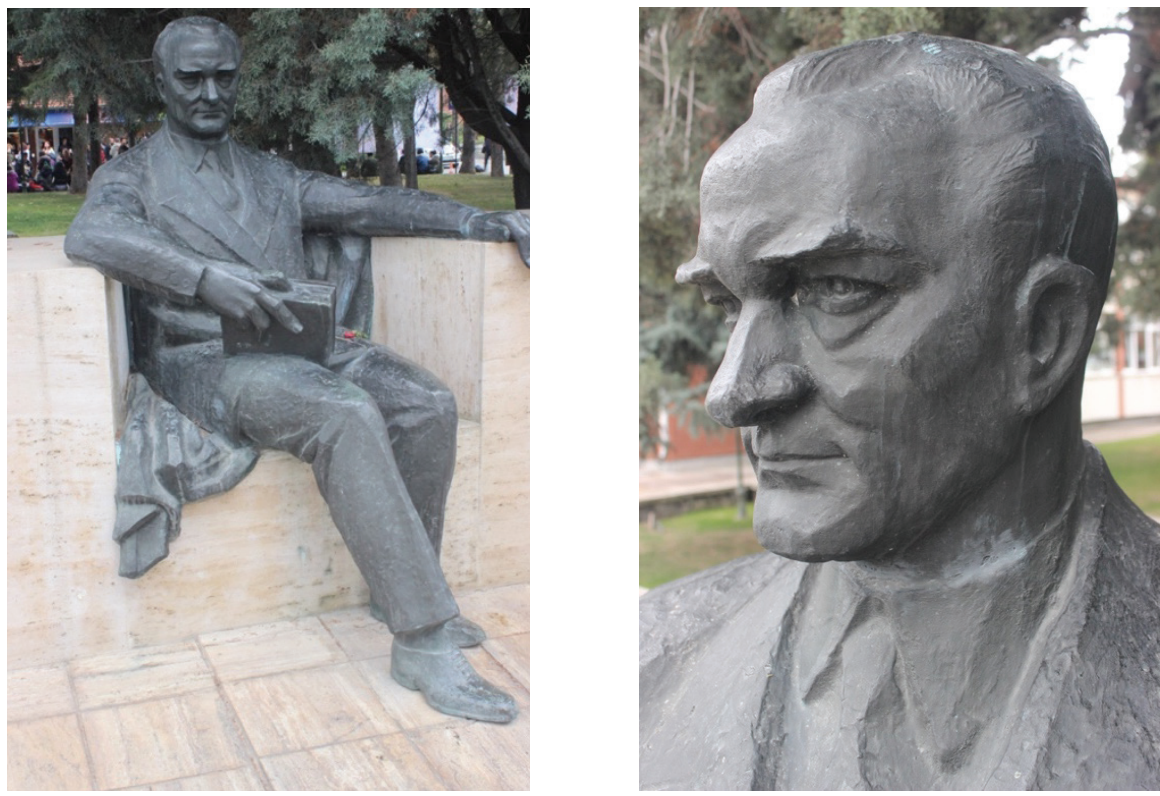

G. 16 ve G. 17: Anadolu Üniversitesi Hukuk Fakültesi önündeki tören alanındaki Atatürk heykeli. (Selda Alp, 2020)

Üniversitesinin tören alanı olarak kullanılan Hukuk Fakültesi önündeki heykel bronz malzeme ile kaide ise traverten malzeme ile tasarlanmıştır ${ }^{38}$. Atatürk heykeli 100x50x70 cm boyutlarında traverten kaplı yatay bir kütle ortasına monte edilmiştir. Yaklaşık $2 \mathrm{~m}$ yüksekliğindeki figür dikdörtgen kaidenin tam ortasında sivil kıyafetlerle oturmaktadır. Atatürk'ün her iki eli kaideye dayanmaktadır. Sağ kolunun dirseği vücuduna paralel olarak dayanmış elinde tuttuğu kitabı göğsüne doğru yatay biçimdedir. Sol kolu kaidenin üzerine uzatılmış biçimdedir. Oturur biçimde duran gövde cepheden gösterilmiştir. Bacaklar dizden bükük biçimdedir. Sol bacak topuktan destek alır biçimde düz olarak yere basarken, sağ bacak öne doğru uzatılmış dizden büküktür. Atatürk'ün sırtından sağ bacağının altına kadar uzanan kumaş üzerine oturmaktadır. Kumaş figürün solunda oturduğu yerde yığın oluşturmaktadır. Bu kumaş yığını figüre hacim kazandırmaktadır. Heykelin önünde $5 \times 6$ m büyüklü-

38 Kaidenin eni $1.11 \mathrm{~cm}$, yüksekliği $1.22 \mathrm{~cm}$, genişliği $5.10 \mathrm{~cm}$; heykelin yüksekliği $200 \mathrm{~cm}$, oturduğu kaide yüksekliği $59 \mathrm{~cm}$, oturduğu yer genişliği $1.22 \mathrm{~cm}$ 'dir. 
günde ve yaklaşı $1 \mathrm{~m}$ eğilimli bir merasim alanı bulunmaktadır. Bu eğim heykele perspektif etkisi yaratırken, oturan figürün daha yüksek olarak algılanmasını sağlamaktadır (G. 16, G. 17).

Atatürk takım elbiselidir. Geniş yakalı ceketi ve düğmeleri detaylı olarak gösterilmiştir. Ceketin içinde dik yakalı gömleği ve kravatı basit biçimde çizgisel bir anlayışla tasarlanmıştır. Kendinden emin, kararlı, sert ve gelecekten umutlu bir yüz ifadesiyle betimlenmiştir. Atatürk'ün yuvarlak yüzü kalın çatık kaşları, ince kapalı dudakları, çıkık elmacık kemikleri vurgulanmıştır. Alnı dışa doğru çıkıktır. Sivri karakteristik burnu ve belirgin köşeli olarak çenesi dikkat çekicidir.

\section{Sonuç}

Şadi Çalık, 1940’lı yıllarda başladığı sanat hayatını 1979 yılında ölümüne dek devam ettiren önemli sanatçılardan biridir. Eserlerinde büst, figür, rölyef, anıt gibi farklı boyut ve biçimlerde eserler yapan sanatçının figüratif soyutlamaları ve soyut biçimleri dikkat çekmektedir. Sanatçı mimari ve kent meydanları ile uyumlu anıtlarıyla 1960'l y yllara damga vuran bir heykeltıraştır. İlhan Koman, Şadi Çalık, Şadi Öziş ve Mazhar Süleymangil'in 1953 yılında Şişli'de kurdukları Kare Metal stüdyosu Türk modern heykelinin, heykel ve mimarlık arasındaki ilişkileri sorguladıkları önemli bir atölyedir. Bu atölyede Türk Grup Espas grubunun manifestosu oluşturulurken, aynı dönemde dünyada başlayan mimarlık ve heykelin bir arada olması düşünceleri savunulmuştur.

Çağdaş Türk heykelinin önemli isimlerinden biri olan Şadi Çalık Atatürk ve Gençlik Anıtı'nda yatay ve dikey oran ile dengeyi çözümlemiştir. Bu anıta benzer çalışmalar ODTÜ Atatürk Anıtı'nda ve Seydişehir Alüminyum Tesisleri Atatürk Anıtı'nda (1973) da devam ettirilmiş, kalabalık kompozisyon anlayışıyla tasarlanmış farklı uygulamalardır. Atatürk ve Gençlik Anıtı'nda kullandığı ellerinde meşale, bayrak taşıyan Türk gençliği heykelleri daha önce yaptığı İzmir Fuarı Lozan Kapısı Meydanı için tasarladığ 27 Mayıs 1960 Devrim Anıtı ile benzerdir. 1990'lı yılların başında kaldırılan İzmir anıtındaki hareketli kadın ve erkek figürleri Eskişehir Atatürk ve Gençlik Anıtı'nda devam ettirilmiştir.

27. ölüm yıldönümü olan 2006 Kasım ayında Anadolu Üniversitesi Çağdaş Sanatlar Müzesi'nde eserleriyle anılan sanatçının üniversite için yaptığ Atatürk anıtının da iki maketi sergilenmiş̧ir. Bu sergilemeler Türk Sanat Tarihi açısından önemli göstergelerdir. Çoğunlukla yok olan sanatçı maketlerinin Çağdaş Sanatlar Müzesi'nde halen saklanmış olması Anadolu Üniversitesi tarihi için oldukça önemlidir. Bu maketlerden küçük olanda rastgele yazılmış harfler sanatçının tasarımında kitabe yazacağını bize düşündürse de yapılan heykelde bir kitabe bulunmamaktadır. Anadolu Üniversitesi'nin Atatürk Anıtı'nda sanatçının ele aldığı biçim dili oldukça etkileyicidir. Anıtta güçlü, 
kuvvetli ve özgüveni yüksek bir birey olarak gösterilen Atatürk çağdaş görünümü ve gençleri kucaklayan kimliği ile tasarlanmıştır. Atatürk bu heykelde sanki öğrencilerle sohbet etmek üzere elinde okuduğu kitaba ara veren ve geleceği emanet ettiği gençliğin başöğretmeni gibidir.

Atatürk ve Gençlik Anıtı ile Atatürk Anıtı'ndaki malzeme seçimi ve uyumu, teknik özellikleri, gösterişsiz ama belli bir plastik özellik gösteren kütlesel köşeli formlarıyla dikkat çeken kendine özgü anıtlardır. Yerleştirildikleri mekanla ilişkiler kurularak tasarlanan anıtlar sanatçının kendi içinde uyumlu ama birbirine benzemeyen anıtlarını düşündürmektedir. Her iki anıtta da Atatürk'ün parmaklarının kemikli ve narin bir biçimde ele alınışı sanatçının imzası gibidir. Her eserinde özgün olma çabasının yansımalarını sunmaya çalışan sanatçının yaptığı Atatürk heykelleri Eskişehir kentinin simgesi olmaya devam edecektir.

Şadi Çalık'ın Atatürk ve Gençlik Anıtı'nı yapması sırasında dönemin gençlerinden biri olan Prof. Dr. Yılmaz Büyükerşen'in de heykel sanatına ilgisi artmış, sanatçı farkında olmadan gerisinde bir heykeltıraşı kente kazandırmıştır. 1969 yılında Akademi müdür yardımcısı olarak çalışan Büyükerşen o yıllardan itibaren kentte yapılan her sanat etkinliğinde yer almış, Yunus Emre Kampüsü’nü heykel ve kabartmalarla donatmıştır.

Sonuç olarak Eskişehir Vilayet Binası önündeki Atatürk ve Gençlik Anıtı ile Anadolu Üniversitesi Hukuk Fakültesi önündeki Atatürk Anıtı'nı ele aldığımız bu makalede dönemin anıları, Sakarya gazetesi yazıları ve üniversitedeki anıtın maketleri bir araya getirilerek değerlendirilmiştir. Eskişehir'de hala yayınlanan Sakarya gazetesinin Atatürk ve Gençlik Anıtı için kent halkını yüreklendirmesi ve yazılarla devamlı olarak anıta dikkat çekilmesi, her toplanan paranın kuruşu kuruşuna açıklanarak anlatılması ve Yılmaz Büyükerşen'in hâlâ süren heykele olan ilgisinin başlangıcına konumlanan bahsi geçen anıtlara dikkat çekilmiştir.

Hakem Değerlendirmesi: Dış bağımsız.

Çıkar Çatışması: Yazarlar çıkar çatışması bildirmemiştir.

Finansal Destek: Yazarlar bu çalışma için finansal destek almadığını beyan etmiştir.

Peer-review: Externally peer-reviewed.

Conflict of Interest: The authors have no conflict of interest to declare.

Grant Support: The authors declared that this study has received no financial support. 


\section{Kaynakça/References}

Aras, Ahmet. "İş ve İşçi Alemi”. Sakarya. 18 Şubat 1959.

Aşkun, İnal Cem. “Anıt Açılırken”. Sakarya, 28 Eylül 1962.

Berk, Nurullah ve Hüseyin Gezer. 50 Yllın Türk Resim ve Heykeli. İstanbul: Türkiye İş Bankas1 Yayınlar1, 1973.

Çalık, Siren. Şadi Çalık. İstanbul: İş Bankası Kültür Yayınları, 2004.

Çetintaş, Vildan. "Rudolf Edwin Belling ve Atölyesi." Doktora Tezi, Hacettepe Üniversitesi, 2003.

Çoker, Adnan. "Soyut heykel”. Boyut 1/8 (1982): 4-6.

Ergin, Muzaffer. “İzindeyiz”. Sakarya. 28 Eylül 1962.

Karakuş, Gökhan. "Kare Metal”, Erken Cumhuriyet Döneminde Mobilya. Der. Umut Şumnu. (İstanbul: Ada Ofset, 2013), 115-118.

Kılıç, Levent. Heykellerle Yaşayan Üniversite. Eskişehir: Anadolu Üniversitesi, 2005.

Koca, Güler ve Rana Karasözen. "1945-1960 Dönemi Eskişehir Modern Kent Merkezinin Oluşumunda Öne Çıkan Yapılar”. Anadolu Üniversitesi Sosyal Bilimler Dergisi 10/3, (2010): 191-211.

Le Groupe Espace. “Le Groupe Espace Manifeste”, L'Architecture d'Aujourd'hui, (37), (1951): 5.

Gezer, Hüseyin. Cumhuriyet Dönemi Türk Heykeli. Ankara: Türkiye İş Bankası Yayınları, 1984.

Oğuz, Sedefhan. Prof. Dr. Orhan Oğuz'un Yaşam Öyküsü. İstanbul: Cem Ofset, 2004.

Özkut, Deniz. “Eskişehir'de Modern Hafizanın Yerel İzleri”. TÜBA-KED 16, (2017): 35-66.

Taşçı, Cemalettin Nabi. Yılmaz Büyükerşen Zamanı Durduran Saat. İstanbul: Doğan Kitap, 2009.

Yasa Yaman, Zeynep. "Siyasi/Estetik Gösterge" Olarak Kamusal Alanda Anıt ve Heykel”. METU JFA 28:1. 2011/1: 69-98.

Yavuz, Ezgi. "Designing The Unity: Türk Grup Espas and Architecture in Postwar Turkey". METU JFA, 32:2. 2015/2: 117-132.

“Heykeltıraş Şadi Çalık’ın yapıtları Anadolu Üniversitesi Çağdaş Sanatlar Müzesinde”. Sonhaber. 23 Kasim 2006.

“Şadi Çalık’ın yapıtları izlenim sunulacak”, Anadolu Gazetesi. 23 Kasım 2006.

“Şadi Çalık eserleriyle anılıyor”. Evrensel Gazetesi. 23 Kasım, 2006.

“Heykel Sanatı’nın öncüsü Sadi Çalık’ın eserleri AÜ’de”. Milli İrade Gazetesi. 23 Kasım 2006.

“Atatürk heykeli için İstanbul'a giden heyet şehrimize döndü”, Sakarya. 25 Mayıs 1953.

"Akademililer bir miting yaptılar. Gençler Atatürk Büstünü Vilayet Önünde muvakkat bir kaideye diktiler”. Sakarya. 21 Aralık 1959.

“9 Temmuzda Şehrimizde Büyük Bir Meydan Toplantısı Yapılacak”. Sakarya. 5 Temmuz 1962.

“Atatürk Anıt1 2 Eylül Günü Törenle Aç1lyyor”. Sakarya. 15 Ağustos 1962.

“Atatürk Anıt1 2 Eylülde açılıyor”. Sakarya. 16 Ağustos 1962.

“Atatürk Anıtına Dikilecek Serenin Değişmesi İsteniyor”. Sakarya. 1 Eylül 1962.

“Atatürk Anıtına Halkın Yardımı Bekleniyor”. Sakarya. 3 Eylül 1962.

“Türk-İş Atatürk Anıtı İçin Kampanya Açtı”. Sakarya. 5 Eylül 1962.

“Gürsel ve İnönü Anıt'ın 28 Eylülde açılışında hazır bulunma için şehrimize geliyorlar!”. Sakarya. 15 Eylül 1962. 
"Eskişehir Atatürk Anıtı Açılış Töreni Programı. Sakarya. 27 Eylül 1962.

“Atatürk Anıtına Kavuşuyor Sevincimiz Çok Büyük. Bugün Saat 15 de Anıt Cumhurbaşkanı Tarafından Törenle Açılacak”. Sakarya. 28 Eylül 1962.

“Cumhurbaşkanı Cemal Gürsel Dün Atatürk Anıtını Açtı!..”. Sakarya. 29 Eylül 1962.

“Kurslar Binasının Arka Bahçesine Akademi Gençlerinin Koyduğu Büst Dün Açıldı”. Sakarya. 24 Kasım 1962.

“İ.T.İ. Akademisinin Vilayetin önüne koymuş olduğu büst tören ile tekrar geri verildi.” Sakarya. 1 Ekim 1962.

“Şadi Çalık 46 yıl sonra soyut heykelleriyle Eskişehir’de”. Sergi Kataloğu. 2006.

Şadi Çalık Sergisi Davetiyesi, serginin aç1lış1 27 Kasım 2006.

http://www.versailles.archi.fr/pdf_actu/programme_andre\%20BLOC\%202015.pdf, Erişim 27 Şubat 2020.

http://www.sanalmuze.org/paneller/Mtskm/09sh.htm Erişim 22 Nisan 2017. 